\title{
Conservação de forragem para ruminantes em silo saco: estratégia de convivência com o semiárido
}

Jéssica Monique dos Santos Lima*, Bismark Alaves da Silva, Beatriz Dantas Fernandes, Francisco Roserlândio Botão Nogueira, Francisco Jocélio Cavalcante Souza, Joandro Ferreira Gomes, Maria Francicarla Nascimento Moura

Instituto Federal da Paraíba(IFPB), Sousa, PB, Brasil

*Autor correspondente

e-mail: jessicamonique_38@hotmail.com

\section{Resumo}

A criação animal possui importância histórica no desbravamento e desenvolvimento do semiárido nordestino, constituindo a principal fonte de renda em terras consideradas improdutivas para monoculturas, principalmente a cana-de-açúcar. Neste território, enquanto grandes latifundiários tinham o controle do rebanho bovino, restava aos camponeses a criação dos pequenos ruminantes e outras criações, atividades geradoras de renda e alimento que permanecem até os dias atuais. 0 semiárido nordestino apresenta características peculiares no que refere-se ao clima e vegetação, onde observam-se poucas chuvas e mal distribuídas ao longo do ano, com alta produção de biomassa vegetal no período das chuvas e, praticamente, inexistente no período seco do ano ou durante secas plurianuais, fator limitante ao desenvolvimento da criação animal. Uma alternativa que vem se mostrando eficaz para superar esta limitação é a produção e estocagem de forragem, principalmente na forma de silagem. Os agricultores familiares constituem a classe mais afetada com a falta de alimentos para os animais, gerando perdas econômicas até mesmo irreparáveis. A conservação de forragem na forma de silagem no modelo tradicional é considerada um desafio para os agricultores familiares, pois este processo demanda muito material forrageiro, maquinário como tratores e ensiladeiras, gastos com lona e dificuldade de manejo. Foi realizado em 2016 um trabalho de mobilização e construção de conhecimento sobre o processo de armazenamento de silagem em seis municípios do interior da Paraíba, com 59 agricultores, a maioria de Assentamentos da Reforma Agrária. A equipe de professores e estudantes extensionistas do Núcleo de Estudos em Agricultura Agroecológica do Sertão Paraibano (NAESP), ligado ao IFPB (Instituto Federal de Educação, Ciência e Tecnologia da Paraíba), com apoio das prefeituras dos municípios parceiros, juntamente com a EMATER (Empresa de Assistência Técnica e Extensão Rural), realizou atividades de conservação de forragem. Utilizou-se silo saco, considerado a melhor alternativa por diminuir custos com mão de obra, espaço, pouco maquinário e melhor aproveitamento do material 
forrageiro. Durante oficinas de formação de agricultores foram confeccionados 151 silos saco de $40 \mathrm{~kg}$ cada, totalizando $7.700 \mathrm{~kg}$ de silagem. Os agentes envolvidos na iniciativa buscaram trabalhar em parceria com famílias agricultoras o desenvolvimento de técnicas condizentes à sua realidade e demanda, desenvolvendo autonomia produtiva e social. A utilização do silo saco promoveu facilidade no manejo das pastagens e dos animais, diminuindo custos, melhorando aproveitamento das pastagens para alimentação do rebanho (principalmente leiteiro, criado em regime extensivo na caatinga) e garantindo renda e alimento para as famílias agricultoras. 